University of South Carolina

Scholar Commons

2018

\title{
In the Spirit of Ella: Race, Community \& Education Reform in New Orleans Post Katrina
}

\author{
Daniella Ann Cook \\ University of South Carolina, daniella.cook@sc.edu
}

Follow this and additional works at: https://scholarcommons.sc.edu/edcs_facpub

Part of the Other Education Commons, Social and Behavioral Sciences Commons, and the Social and Philosophical Foundations of Education Commons

\section{Publication Info}

Published in The High School Journal, Volume 101, Issue 2, 2018, pages 90-99.

Copyright (@ 2018 The University of North Carolina Press

Cook, D. A. (2018). In the Spirit of Ella: Race, Community \& Education Reform in New Orleans Post Katrina. The High School Journal, 101(2), 90-99. doi:10.1353/hsj.2018.0002

This Article is brought to you by the Instruction and Teacher Education, Department of at Scholar Commons. It has been accepted for inclusion in Faculty Publications by an authorized administrator of Scholar Commons. For more information, please contact digres@mailbox.sc.edu. 


\title{
In the Spirit of Ella: Race, Community \& Education Reform in New Orleans Post Katrina
}

\author{
Daniella Ann Cook \\ COOKDA2@mailbox.sc.edu
}

I would open up my talk by saying that there was a man who had a health problem and he was finally told by the doctor that they could save his sight or save his memory, but they couldn't save both. They asked him which did he want and he said, "Save my sight because I would rather see where I am going than remember where I have been." I am saying as you must say, too, that in order to see where we are going we not only must remember where we've been, but we must understand where we have been. This calls for a great deal of analytical thinking and evaluation of methods that have been used. We have to begin to think in terms of where do we really want to go and how can we get there.

Ella Baker

1969 Speech Institute for the Black World in Atlanta Georgia

p. $230-231$

It was a clear day in February, 2008. I was driving home after two days away writing and grappling with the data I had collected for my ethnographic study of Black educator experiences with school reform in New Orleans post Katrina. Traffic was light, the sky blue and clear. I was feeling good until the call. Seeing the phone number of Ruth, the youngest of the teachers in my study, I anticipated and looked forward to hearing her voice, touching base and catching up. However, this conversation was not what I expected. Her voice was weary as she began; another one of her students had been killed. Quietly and with a brokenness in her voice, she shared that she was thinking about drinking and taking pills until she would be able to lie down and not wake up. At that moment, our silence was deafening. The complexity of the question she then posed was almost missed because of its seeming simplicity, "What will I do with her story and the stories of the other teachers?". In that moment, I answered "I will tell your stories as best I can and promise not to forget".

Even now, my response feels insufficient. I remember feeling helpless and completely unprepared to deal with the actual trauma experienced by those whose lives were impacted by Hurricane Katrina and her aftermath. According to the first major investigation of survivors' mental health status, the rate of mental illness doubled after the storm. Approximately $15 \%$ of the 200,000 residents of counties and parishes struck by the storm suffered from anxiety, depression, post-traumatic stress disorder and other forms of mental illness (Kessler, Galea, Jones \& Parker, 2006). On May 1, 2006, Brian DeBose reported in The Washington Times that

nearly all of the facilities that used to handle psychiatric care in the city are closed, leaving private hospitals unaccustomed to handling the volume of patients who 
need such treatment to pick up the slack. Tulane University and Toureau hospitals are the only emergency rooms open in New Orleans and ...people who are in protective custody for suicidal and other psychiatric maladies have to wait three to five days for a psychiatric bed (p. 1).

Ruth was not alone in her struggle to cope with the emotional and psychological aftermath of the storm as she chose, like so many other educators, to return to her students in New Orleans. Certainly, my choice to render their stories using composite character counterstorytelling was an answer to Ruth's call. The compelling honesty and implicit charge of Ruth's question serves as a haunting reminder that the work of a radical democratic transformation of public education is a process of struggle for justice and that equity must be rooted in and out of a relationship with community.

Dedicating her life and work to advancing racial justice, Miss Ella Jo Baker was the Fundi of the American Civil Rights movement (Preskill, 2005) as she "possesse[d] practical wisdom and [was] skilled at passing on to new generations the knowledge that the community's elders regard as important” (p. 1). In the numerous stories told of Miss Baker, her tremendous ability to really listen and her knack for asking questions have always stood out to me. In her biography of Ella Baker, Ransby (2003) noted

She was a consummate teacher," one SNCC member recalled, "never pounding us, 'You must do this, you must do that,' [but simply] by raising questions. So, what are we trying to accomplish? She would probe. Are we all in agreement? What do we really mean by that? These were her kinds of questions. Her method of inquiry often helped anchor or center an unwieldy conversation. Another SNCC activist made similar observations: "Miss Ella would ask key questions, and through asking of the questions, certain things became revealed (p. 328).

After Miss Baker's death in 1986, Anne Braden “spoke of Ella Baker's ability to sift through the superficial to find the real human being. She didn't deal in labels. She wanted to know what people thought, but mostly she wanted them to think" (p. 226). It is in this spirit that I approach and write this commentary on the 2006 Special Issue After the Flood: The Impact of Katrina on Education in New Orleans.

Over 10 years later, many are still frustrated, though not surprised, with the insufficient, inhumane and collective inability of school reformers to grasp the monumental changes that occurred in the schools, and more importantly the communities, of New Orleans after Hurricane Katrina. Taken together, the pieces within the 2006 Special Issue pose questions about how those who are committed to equity, social justice and human liberation might collectively work with communities to provide a quality education for all students. Sadly, the questions and insights from the authors in the 2006 Special Issue were profound and regrettably prophetic. Since its publication, a growing body of scholarship has addressed public schooling in New Orleans post Katrina. Scholars and researchers have explored the impacts of charterization on student achievement, equity and access (Dixson, Buras \& Jeffers, 2015; Dixson, 2011), racial and economic formation of public schools (Huriya, 2016; Buras 2011a, 2011b, 2011c; Buras, Randels, Salaam, \& Students at the Center, 2010, 2005, 2007, 2009), the impact on African American teachers (Cook, 2010; Cook \& Dixson, 2013;) and the wide range of exclusionary practices - from harsh discipline to ignoring special education needs - that cut kids off from receiving education (Wolf, N. L., 2011; Simmons, 2009, Robinson \& Brown, 2007). As noted by Linda Darling Hammond's reflections on Katrina, "There are events of such enormous historical importance that a single word takes on symbolic meaning: "Watergate" connotes political corruption. "Brown" has 
come to denote a commitment to equality. And "Katrina" has come to signify both governmental neglect and institutional racism" (p. xii). Undoubtedly, Katrina has symbolic meaning for education in the age of market based efforts to revamp, and arguably dismantle, public education.

New Orleans post Katrina, and the school reforms enacted despite the communicated desires of the communities, is a stark reminder of the limits of the free market approach to guarantee access to a quality education. The unbridled glee of those supporting neoliberal reforms of charters and choice is aptly captured by Paul T. Hill's (2005) statement, "In the case of post-hurricane New Orleans, American school planners will be as close as they have ever come to a green field opportunity: a large public education system will need to be built from scratch.” (p.1). This sentiment echoes throughout statements made by and actions of people and policy makers who sought to decentralize public education. The glee of the reformers who sought to implement a privatized approach as a remedy for the shortcomings of public education in New Orleans failed to take into account the racial, cultural and economic complexity of New Orleans. As noted in the 2010 Southern Poverty Law Center Special Report Access Denied, Belway remarked,

The rest of the country is looking to New Orleans as a model for educational reform and innovation. The testimonials contained in this report from families and students provide a cautionary tale for school districts and states looking to New Orleans for solutions to the issues that vex public schools across the country (p. 3).

The challenges to students receiving a "world class education" as promised after Katrina plagued New Orleans public schools prior to the storm.

According to the US Census Bureau (2000), although the population of the city was $67 \%$ African American, the public-school population was 96.1\% African American which indicated that most of the White school aged children attended private schools. In January 2006, 20 public schools were opened. By 2012-2013, there were 90 public schools enrolling 43,000 students with $84 \%$ of students attending a charter school. The Recovery School District (RSD) had oversight of 75\% of the schools and enrolled $70 \%$ of all public school students. After more than a decade of decentralized public schools, the unification of public schools in Orleans Parish is on the near horizon. Passed on May 12, 2016, by the Louisiana Legislature, Act 91 mandates the amalgamation of public schools in Orleans Parish under the oversight by the Orleans Parish School Board and its superintendent by July 1, 2018.

This essay incorporates over 10 years of work and research in New Orleans. Since October 2005, I have learned much about equity, race and education from and with students, teachers, parents and various organizations working in New Orleans. These include the National Coalition for Quality Education in New Orleans (NCQENO), United Teachers of New Orleans (UTNO), Students at the Center (SAC), Pyramid Community Parent Resource Center, Concerned Educators of New Orleans and the Annenberg Institute for School Reform at Brown University. The data include my personal notes, interviews and focus groups data for different research projects. From this work, one thing is abundantly clear: post Katrina reform efforts were not deeply rooted in nor out of the experiential knowledge of teachers, educators and the local community.

Drawing upon Linda Mizell's notion of educational institutions gives us another way to think about the communal responses to, and possibilities emerging from, efforts to 
reform public schools post Katrina. After an overview of Mizell's notion of educational institutions, the perspectives of local communities are used to explore two emergent themes about the nature of market-driven, decentralized approaches in post Katrina New Orleans - namely, the lack of accountability to the community and illusion of choice.

The Role of Educational Institutions. Within pre-and-post Katrina New Orleans, educational institutions offered opportunities for education beyond what was present in public schools. Linda Mizell (2010) uses the term educational institutions rather than schools to challenge the pervasive assumption that African Americans do not value education and that access to education was given rather than hard won. Specifically, she explores how the historical struggle for equal access to educational opportunity was not limited to schools but extended to "every sphere in which African Americans recognized the possibilities for expanding their knowledge of the world" (2010, p.xvii). Mizell's (2010) work makes two contributions useful to this discussion. First, her synthesis of the scholarship on African American educational history and philosophy challenges the assumption about African Americans not caring about education noting that "no people cared more, literally risking life and limb in order to attain it" (p.xvii). Furthermore, her analysis uncovers the ways in which "[t]he scholarship challenges the perception of education in general and schooling in particular as something that was given to African Americans" (p.xvii). In many ways, these two assumptions African Americans not valuing education and education as given to rather than hard fought - operated in the shape and response to post Katrina New Orleans school reforms. The African American community deeply cared about the education of children in New Orleans and the struggle for access to a quality education has continued. In the tradition of the Southern-based Black-led freedom movement, the struggle for educational opportunity and a quality education in New Orleans continues.

What follows centers on several questions emerging from and inspired by my (re)reading of the 2006 Special Issue. These include: how would our work in secondary schools look different if we acknowledge the centrality of education to the freedom struggle to transform educational possibilities for black and brown communities? How does Mizell's educational institutions expand our historical and contemporary understanding of communities' responses to inequitable contexts in ways that support access to quality education? What can we learn from their responses or, rather, how can our contemporary struggles for realizing the democratic possibilities of public education learn from their responses? Many answers can be found in the narratives of parents, teachers and students with the presence and importance of the community in New Orleans as central to understanding how the struggle might move forward.

\section{The Limits of Market Driven, Decentralized Approaches}

In reflecting on the changes in how public schools were structured after Katrina, a twenty-one year veteran black educator noted "just because you have new things and the best of things, that says nothing about kids still being educated.” In my analysis, several dominant themes emerged about the failures of the market driven charter approach to deliver a quality education to all students in New Orleans post Katrina. With autonomous schools having little accountability to parents and the larger community, choice is and was an illusion without the mechanisms to ensure communication. Though New Orleans had ample teachers in the pipeline, retention and distribution of teachers was inequitable. The over-emphasis on competition among schools minimizes the basis for collaborative partnerships across schools and with communities reinforcing the traditional flow of resources shaped by class and race 
politics. Structural barriers limited parent and community participation in decision making indicated specifically by the lack of easily accessible information, the individual rather than communal understanding of parental involvement, and the disregard for community dissatisfaction with the changes made in the name of reform. The notion of educational reform has not been and still is not neutral.

Community understanding of accountability. The community cultivated a strong sense of accountability to the larger well-being of students served by public schools. In this sense, the New Orleans community was a strong protective factor that instilled a sense of history, culture and belonging despite structural and persistent problems. This sense of responsibility to students extended beyond traditional family lines. It was inclusive of the entire community. At a meeting of her child's charter school board, a parent recounted "I said I'm advocating representing kids who don't have anybody speaking for them. In so many words I was told, 'You're a different kind of parent."”. When she countered by suggesting that "...we have a parent liaison or advisory committee of parents," the response by the charter school board was "[that] it was a good idea but we don't think parents should be a part of decision making." This is a complete contradiction to notions of parental choice which supposedly undergird the arguments for autonomous schools.

To be clear, my reading and reflection of the pieces does not undermine the significance or devastating impact of the storm. Rather, I see these narratives as speaking to the larger issues of structural inequality and systematic unequal opportunities to learn, buttressed by the larger narratives of those found in mainstream discussions of public education: the public is the problem with the market being the solution. A strong and recurrent theme was the missing human and arguably humane element to rebuilding public education and the city in general. Without an intentional effort to attend to the social and emotional needs of the students, teachers, families and larger communities, any effort to rebuild was doomed.

One parent participating in a focus group on charter schools in New Orleans stated “she [the principal] doesn't get that you don't come in and impose. You can never convince me that charters elevated my voice. We need people who trusted that our information was good even if it does not agree with their message or beliefs". The message about the role of parents and the community at large was limited and echoed in other statements from the school reform leaders. The community writ large, especially parents, was not a trusted source of information about their own experiences and, as importantly, their understanding of the meaning and substance of a quality education for their children. The ethics of parents and community leaders was more aligned with Ms. Baker's as they too believed in the importance of "trying to relate to people and share whatever capacity I have to help them to use [their own] capacities. [Ella Baker] tried to facilitate those who are involved with struggle and who struggle not just for themselves" (Grant, 1998, p. 224). The community of New Orleans, including parents and teachers, operated from the vantage point that public school students were their children.

Voting with your feet: The power of an illusion. The illusion of voting with your feet has been touted as evidence for how parents have choice in a decentralized school system. This dominant narrative and operating assumption by Paul Hill and many other advocates for market-based approaches is refuted by the experiences of parents and acknowledged reticently by school leaders. When asked about the role of parents and the larger community, a principal at a Recovery School District school responded 
Parents have less of an opportunity. I think it's important for parents to have an avenue to influence decision making and give feedback, but I don't know if they should be directly involved. I feel like the parents are the consumers that give feedback. Our management team is held accountable to meet their desires and needs. One of the things that is empowering parents right now is the freedom of choice they have to choose among public schools in New Orleans. I think it's more productive for parents to leverage that power and communicate their feelings but not have them on a charter board or anything.

Parents, and by extension the larger community's, role in educational decision making is providing feedback. This approach does not require having access to the tables where decisions are being made. Furthermore, it ignores the power held by those at decision making tables when they choose not to listen to, acknowledge and meaningfully respond to feedback from those impacted by their decisions. As a parent observed,

In the market-based model if the school doesn't serve you well, leave. But you have to go through the process of realizing that the school has failed your child, and then shop for something else. I've lost two weeks at a time from work over this. Plus, we are working around the challenge of there is no central system. Only to be told yes, maybe, we don't know, call back or being placed on a waiting list. A lot of parents just give up.

This was the experience of an involved parent who applied aggressive attention to the children's education. If one espouses the existence of a high quality system of choice, the system must be rooted in all choices being high quality. This was, and is, not the case in post Katrina public school options.

Given the absence of clear channels of communication coupled with little accountability to the communities being served, the system of schools created after Katrina were designed to frustrate. As one Orleans Parish School Board district leader noted "Education is now to the point where people don't have a point of contact for all these other services. It's difficult for people to know who do I get in contact with for what and how do I contact them". Autonomous schools are perceived to have little accountability to parents and the larger community. As a result, principals serve as gatekeepers with no accountability. Another parent reported

I went to board meetings. I saw a bunch of men with no relationship to the school saying all the kids had ADHD. There was no opportunity for me to speak - I was not even introduced. The charter board did not have any attachment or relationship to our community and the children that they're there to serve.

Knowing the community as foundational to having a relationship with the school is central recurring theme of the 2006 special issue. The observations and insights from the 2006 Special Issue have enduring relevance to understanding what Ladson-Billings (2007) coined "aggressive neglect" within education responses and reforms. LadsonBillings (2006) characterization of aggressive neglect as the dissimilitude of experience with one segment of society experiencing unprecedented poverty and others unparalleled wealth speaks to the ways in which growing income disparity reduces the reality of educational opportunity. Furthermore, she affirms, "Indeed, what we see in our cities is no longer just about social and civic responsibility. It is about moral responsibility. We cannot call ourselves a moral people in the midst of this aggressive neglect" (p.9). A poignant example of the dissimilitude of experience of schooling is the perception of the Recovery School District as the approved dumping ground. 
The Recovery School District schools were in essence the public of public schools in New Orleans as they enrolled students who were unable to choose other options as a consequence of being forced out by selective admissions policies. The misguided focus on school choice as the solution to historical legacies of practices and polices relegating African American children to second-class schooling is best captured by a comment made during an interview by a Recovery School District charter school leader. In reflecting on the reforms,

Another challenge in the city, not necessarily for us, is the RSD has in some ways become schools of last resort for students and teachers. They are educating half of the students in the city. It's a real challenge. Schools are better than they were before, but equity is a big challenge and certainly concerns me. It's easy for me to say we're not RSD, we are an RSD charter. But there's a part of me that doesn't like saying that because it's a hard truth that somebody's a winner and somebody's a loser.

In many ways, the 2006 Special Issue anticipated and worried about the deleterious impacts of the autonomous school model embraced by the post Katrina educational reforms. A self-proclaimed "skeptical advocate for charter schools" (p. 70), Tillotson (2006) expressed "And while I deeply believe in school choice for our most vulnerable students, who usually could benefit most from the best schools and instead are saddled with the worst, I know that often it is schools who are choosers of students and not the other way around" (p. 70). After performing needs assessment in New Orleans for six months after Katrina, he described "What [he] saw was simultaneously inspiring and depressing, with dark clouds teetering on the horizon" (p. 70). Likewise, the aforementioned observation by the charter school leader painfully confessed the inequitable outcome of the lack of accountability in autonomous school reform models is consigning, and in many ways affirming, black children - many of whom are school dependent - to the status of losers in the educational system.

To me young people come first, they have the courage where we fail

And if I can but shed some light as they carry us through the gale

The older I get the better I know that the secret of my going on

Is when the reins are in the hands of the young, who dare to run against the storm

Ella's Song

Reagon, B. J. (1993)

The complications and confusion surrounding rebuilding public schools in New Orleans post-Katrina was juxtaposed by the underlying narrative of Students at the Center (SAC) pieces which centered on cultivating community as an integral process for understanding how to build a more democratic and just education system. I found myself drawn to the intimate iterative cycle in a relationship among writing, listening, teaching, and learning as a means for understanding. Not surprisingly, this was especially evident within the narratives of students and teachers from the Students at the Center (SAC). Ms. Baker's pedagogical and leadership style understood the importance of listening to and learning from young people. As a junior at McMain Secondary School, Janay Barconey shared

... I've lost my home, my friends, and my school. I'm always on the verge of tears. But the worst part of it all is that the public officials - both elected and hired - who are supposed to be looking out for my education has failed me even worse than the ones who abandoned me at the Superdome. My family and friends have food and 
water and the kindness of strangers. But we still don't have control of our lives, and we're still being abandoned by local, state, and federal officials the things I didn't expect to see ended up hurting me the most (p. 32).

Janay echoes the dismay and disappointment by parents and teachers who also expected more from those making decisions about schools. The patterns of those making decisions about the education system most often excluded the very people most impacted by those decisions: the students.

Chris Mayfield, a veteran public school teacher in New Orleans, explored the use of writing to help students process their Katrina experiences. His reflection is a reminder that good methods are only good if used appropriately and within a particular context. He spoke about the students being tired of talking about Katrina and the groans that he elicited from his class when asking them to do so. One particular comment stood out to me from his narrative, “... the effort and discomfort involved in reflecting on the city's tragedy had outweighed any therapeutic benefits. In addition, I started to understand that the turbulence of the historic storm had been for many of my students only a peak in the many challenges they had already faced as young African-Americans in one of the nation's poorest cities, and that they had a lot of other things to think about besides Katrina.” (p. 32). The acknowledgement of this teacher emerged from his being able to recognize and respond to his students' understanding of their current social location. Mayfield's response echoes Jim Randel's reflection that “[a]s always, the students had plenty to teach the adults in attendance" (p. 48).

In Resistance ${ }^{1}$, Andrida Kelly (2006) identified that a recurring theme was

the notion that mis-education can be as damaging a condition as enslavement or ignorance. I am clearly angered by my lack of knowledge of African history, but in retrospect I'm not sure that my ignorance of Africa is the real source of my angst. Rather, I think that the notion of being conditioned to subscribe to a binary logic that informs every tenet of our society - right and wrong, rich and poor, black and white- is the real problem I had with my education up until that point” (p. 45).

In their own ways, the narratives of Kelly and Barconey affirms the centrality of schooling in realizing the democratic promise of education. The binary logic that encapsulates the questions most often posed about whether schools as a proxy for education are better or worse after Katrina misses the point. Delpit and Payne (2007) cautioned "the nation must pay the most careful attention to the children of New Orleans if we don't want the broken levees to sweep away the futures of children as they swept away so many homes and lives" (p. 2). The questions we ask of any school reform effort should focus on whether they advance the goal of fulfilling the democratic possibility of education. Doing so would require having a sense of history as a way to understand the roots of educational inequality and strategically countering with routes to fight against unfair distribution of educational opportunities.

Described as Miss Baker's grandchildren, Payne (2010) asserts that the young people of the Baltimore Algebra Project (BAP) embodied thoughtful, self-aware and other-aware hell-raising youth. Running a tutoring program with a sense of history, means that

\footnotetext{
$\overline{1}$ Kelly wrote her essay, Resistance, as a senior in high school. It is drawn from her work with her teacher Mr. Randels, co-founder of Students at the Center (SAC). Kelly's essay was inspired by their working closely with the African American History Alliance of Louisiana to commemorate the 1811 Slave revolt. For a fuller description, see her piece, Reflections on Writing Resistance, in Special Issue (p. 43-46).
} 
when something goes awry, the young people of the BAP have models for interpreting it, which others would not have. They have models for reacting, which others would not have" (p.5). Payne notes that "If young people are very conscious of themselves as historical actors, many of the officials with whom they are butting heads seem oblivious to how much they look and sound like the power brokers of the past (and some of today's gatekeepers are Black)" (p.7). The writings from the Students at the Center have a sense of history which was central to their articulation of how they understood their schooling experiences in New Orleans post Katrina.

Arguably, the neoliberal school reforms operated from a different sense of history of the New Orleans schools and community. Act 35 was passed when little resistance could be mounted and communities mobilized as the people and educational institutions of New Orleans were in the midst of coping with the devastation of the storm. This was intentional not accidental. The neoliberal response to Hurricane Katrina blatantly ignored human suffering and therefore lacked humane understanding of the human crisis. As such, it was, and will always be, limited in efforts to authentically respond to the educational and human needs of minoritized and marginalized communities. Given the response to Puerto Rico in the aftermath of Hurricane Maria, our political leadership still has yet to learn this fundamental lesson from Katrina.

\section{Conclusion}

New Orleans, like the rest of the United States, has not had the political will necessary to commit to providing a quality education for all students especially those who bear the brunt of inequitable schooling opportunities. In assembling the special issue, a primary aim was to highlight neglected truths that offer alternative renderings about education reforms in New Orleans post Katrina. The people who lived and worked in New Orleans had a clear understanding of the inequities existing in the public schools and insight into remedies. These understandings were rooted in a sense of community and history.

For scholars and practitioners committed to educational justice in the complex field of secondary education, we must center the voices, perspectives and knowledge of local communities in our national deliberations about education. The content of our ideas and actions must be informed by the lived experiences and historical knowledge of local communities and intentionally include young people. We must continue to pose questions and offer solutions that are rooted in the local communities. The process and content of our work regardless of subject, level or discipline must be imbued with a sense of history that deepens our understanding of where we have been. We must tell their stories and listen when they do so. We must promise not to forget.

\section{References}

Balch-Gonzalez, M., Cook, D. A., \& Richards, E. (2010). Community Organizing for Reform at Scale: Balancing Demand and Support. Going to Scale with Smart Systems, 33.

DeBose, B. (May 1, 2006) Katrina Trauma Besets the Big Easy, The Washington Times. Retrieved from http:// www.washtimes.com/national/20060501-123001-9306r.htm

Buras, K. (2011) Race, Charter Schools, and Conscious Capitalism: On the Spatial Politics of Whiteness as Property (and the Unconscionable Assault on Black New Orleans). Harvard Educational Review, 81(2), 296-331.

Collins, P. H. (2013). On intellectual activism. Philadelphia, PA: Temple University Press.

Cook, D. A. (2010). Disrupted but not destroyed: Fictive-kinship networks among Black educators in postKatrina New Orleans. Southern Anthropologist, 35(2), 1-25.

Cook, D. A., \& Dixson, A. D. (2013). Writing critical race theory and method: A composite counterstory on the experiences of Black teachers in New Orleans post-Katrina. International Journal of Qualitative Studies in Education, 26(10), 1238-1258. 
Delpit, L., \& Payne, C. (2007). Katrina's Last Victims? In New Orleans's reorganized school district, the neediest are getting left behind. NATION-NEW YORK-, 284(1), 20.

Dixson, A. D., Buras, K. L., \& Jeffers, E. K. (2015). The color of reform: Race, education reform, and charter schools in post-Katrina New Orleans. Qualitative Inquiry, 21(3), 288-299.

Dixson, A. (2011). Whose choice? A critical race perspective on charter schools. The neoliberal deluge: Hurricane Katrina, late capitalism, and the remaking of New Orleans, 130-151.

Grant, J. (1999). Ella Baker: Freedom Bound. Hoboken, New Jersey: Wiley.

Hill, P. (2005). Re-Creating Public Education in New Orleans. Published Online (Education Week): September 20, 2005 Published in Print: September 21, 2005, as Re-Creating Public Education In New Orleans.

Huriya Jabbar. (2016) The Visible Hand: Markets, Politics, and Regulation in Post-Katrina New Orleans. Harvard Educational Review 86(1), 1-26.

Kessler, R. C., Galea, S., Jones, R. T., \& Parker, H. A. (2006). Mental illness and suicidality after Hurricane Katrina. Bulletin of the World Health Organization, 84(12), 930-939.

Ladson Billings, G (2006). Now They're Wet: Hurricane Katrina as Metaphor for Social and Educational Neglect. Voices in Urban Education 10 (Winter), 5-10.

Mizell, L. (2010). The Holy Cause of Education: Lessons from the History of a Freedom-Loving People. In Perry, T., Moses, R. P., Cortes Jr, E., Delpit, L., \& Wynne, J. T. (Eds). Quality education as a constitutional right: Creating a grassroots movement to transform public schools. Boston, MA: Beacon Press. xvi-xxii.

Preskill, S. (2005). Fundi-The Enduring Leadership Legacy of Civil Rights Activist Ella Baker. Advancing Women in Leadership, 18, 1-10.

Ransby, B. (2003). Ella Baker and the Black freedom movement: A radical democratic vision. Chapel Hill, NC: University of North Carolina Press.

Reagon, B. J. (1993). Ella's Song. Sweet Honey in the Rock. We Who Believe in Freedom: Sweet Honey in the Rock... Still on the Journey.

Robinson, S. P. \& Brown, M. C. (2007). The children Hurricane Katrina left behind: Schooling context, professional preparation, and community politics. New York, New York: Peter Lang.

Simmons, L. (2009). End of the line: Tracing racial inequality from school to prison. Race/Ethnicity: Multidisciplinary Global Contexts, 2(2), 215-241.

Wolf, N. L. (2011). A case study comparison of charter and traditional schools in New Orleans recovery school district: Selection criteria and service provision for students with disabilities. Remedial and special education, 32(5), 382-392. 